\title{
FALA, SERVIDOR
}

\section{A REFORMA ADMINISTRATIVA EM PERGUNTAS E RESPOSTAS}

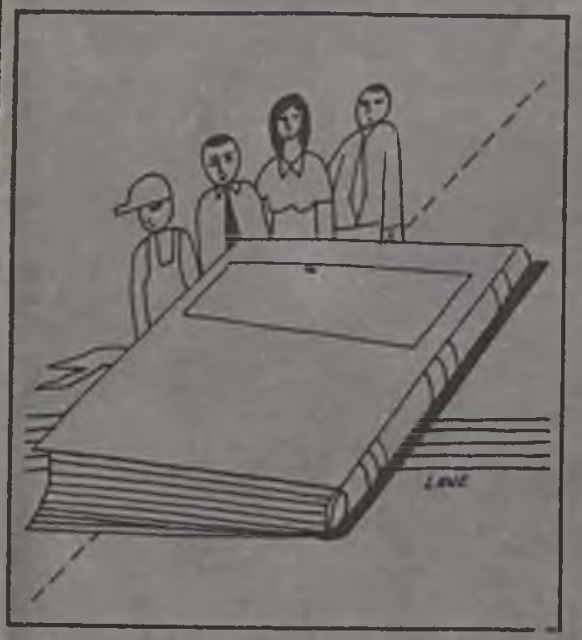

\section{CLT-Estatuto}

Marcelo Pereira dos Santos, do Rio de Janeiro, pergunta:

1. Trabalho na Fundação Nacional Pró-Memória, órgão da administração indireta, subordinado ao Ministério da Cultura, como celetis. ta, poderia optar pelo Estatuto dos Servidores, na reforma administraliva?

2. Perto de minha residência cuiste um órgão da administração direta. Com a reforma administrativa, teria a oportunidade de fazer esta opcão, em virtude dos gastos com passagem? 3. Teria oportunidade de fazer essa opcüo en 1986?

Giselda Lopes do Rega Pinlo. secretária-cieculiva da (i)missio de Reforma, respondc:

1. De acordo com a legislação vigente, servidur de fundação nảo pode optar pelo regime estatutário. nem ser transferido para órgio da administraçăo direta, que $1 \mathrm{~cm}$ sistema de classificafăo de cargos próprio, aprovado pela Lei 5.645 , de 1970.

2. Somenle com a aprovaça, pelo Congresso, do anteprojeto da Lei Orgânica da Administração Pública lederal, é que se poderá saber quais os órgãos públicos da administração federal (territórios e aularquias federais) cujo sistema de pessoal será regido pelo Estatuto.

Portanto, os quesitos 1, 2 e 3 de sua carta somente poderão ser res- pondidos afirmativamente ou não quando da consecução das medidas focalizadas nos itens $1^{\text {a }}$ e $2^{\text {a }}$ da presente.

\section{Unificação}

Maria José de Aguiar Silva, Lagarto, Sergipe, quer saber:

Sou servidora pública, regida pela CLT. Trabalho no IAPAS desta cidade. Conto trinta anos de servico e quero requerer aposentadoria. Mas alguns colegas dizem que eu devo esperar porque vamos passar para estatutários. Dizem também que já consta do novo Estatuto essa facilidade. Peço esclarecimentos que me dêem condiçoes de fazer a escolha.

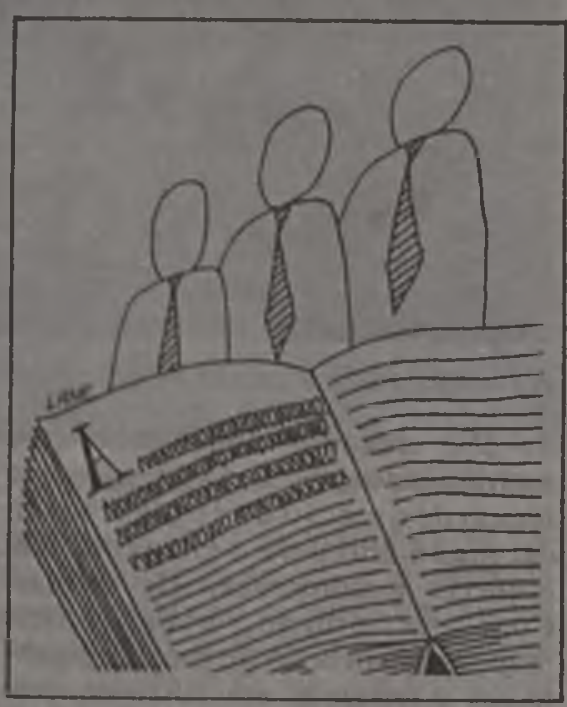

Ciisclda Lopes do Rego Pinto, scicrétária-cexceuliva da Comissão de Reforma, responde:

1. O Artigo 177 do anteprojeto de Estatuto, aprovado pela Comissão de Reforma, está assim redigido:

"Arı. 177 - A inclusão, no regime deste Estatuto, dos servidores regidos pela Legislação Trabalhista pertencentes aos órgãos da Uniào. Territorios e autarquias, será objeto de lei especial"';

2. O governo, através do Ministério da Administração, está examinando a possibilidade de instituir a carreira do Servico Público Federal, erı substituiça ao que existe, sob um único regime juridico;
3. A unifiçação dos atuais regimes (estatutário e celetista) dependerá do que ficar resolvido em relação à mencionada nova carreira do servidor público.

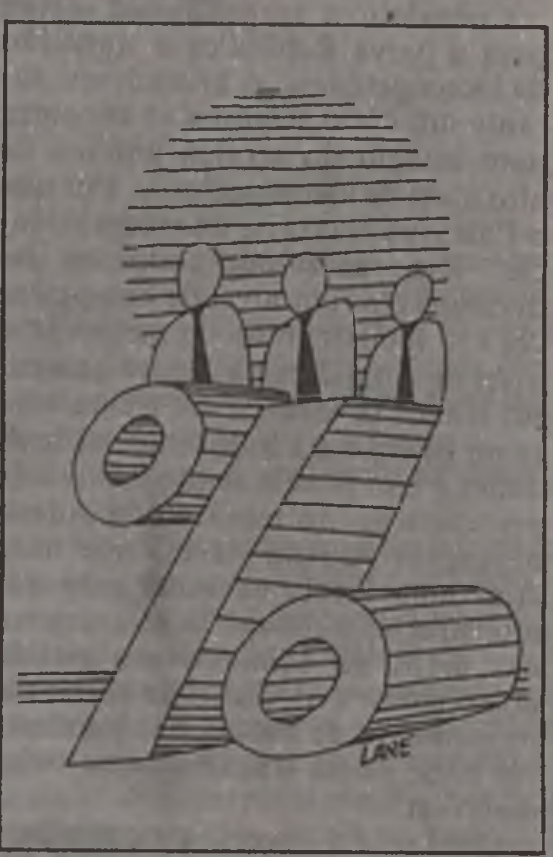

\section{Aposentadoria}

Nelson Barreto Coutinho, médico celetista do Inamps, Aflitos, Recife, Pernambuco, pergunta:

Ao aposentar-se, o servidor celetista que trabalha também como autônomo junta obrigatoriamente os tetos das contribuiçoes e tem seus proventos reduzidos a cerca de $50 \%$, penalizando inclusive sua familia. O nıesmo não ocorre com o estatutário que não junta seu teto de contribuição com o de autônomo, podendo, inclusive, aposentar-se como funcionário e continuar como autônomo, ou vice-versa. A Reforma Administrativa vai corrigir essa injustica?

Célio Franca, secretárioexecutivo da Secretaria de Desburocratização, responde:

Essa questão é objeto de estudo na Comissāo de Reforma AdminisIrativa e sua solução será possivel a partir da unificaçăo dos regimes juridicos que reunirá todos os servidores em uma só categoria. 